Short communication

\title{
Monitoring for conservation in African tropical national parks: An agenda towards policy-relevant science
}

\author{
Ruppert Vimal \\ German Centre for Integrative Biodiversity Research, Halle-Jena-Leipzig, Deutscher Platz 5e, 04103 Leipzig, Germany \\ Institut Dissonances, Le Village, 09800 Bonac-Irazein, France
}

\section{A R T I C L E I N F O}

\section{Keywords:}

Monitoring

National parks

Social drivers

Evidence-based conservation

Biodiversity

Africa

\begin{abstract}
A B S T R A C T
Monitoring as an instrument to quantify human and wildlife activities has been increasingly recognized as fundamental towards efficient biodiversity conservation strategies. Promoting the need to direct management based on scientific guidance, monitoring reflects the rise of evidence-based conservation approaches. Nonetheless, in tropical national parks, monitoring programs can fail to address conservation issues and divert scarce resources away from management priorities. In this manuscript, drawing on the literature and recent empirical observations in seven tropical national parks, I argue that the implementation of monitoring must go beyond the rational model of transfer from science to policy and focus on the processes of co-construction between knowledge and action. An increase in social engineering is needed among partners, services and hierarchical levels of parks to ensure a coherent strategy of knowledge production and its use for decision. I provide concrete recommendations as levers of action towards monitoring efficiency and policy-relevant conservation science.
\end{abstract}

\section{Introduction}

Tropical national parks have been widely recognized as fundamental strategic areas for the protection of major biodiversity hotspots and critically endangered species (Beaudrot et al., 2016; Saout et al., 2013). Such areas, however, often face many different threats, political instability, and their effectiveness in protecting nature might be questioned (Miteva et al., 2012; Tranquilli et al., 2014). As an instrument to quantify human and wildlife activities, monitoring is fundamental for natural resources management (Margoluis and Salafsky, 1998; Stem et al., 2005). It attempts to provide scientific guidance towards reliable action, management efficiency and increasing conservation outputs. Hence, monitoring can be considered as a tool for evidence-based conservation (Pullin and Knight, 2001).

However, it has been widely reported that, in developing countries, monitoring efforts are often ineffective in addressing conservation issues (Burton, 2012; Danielsen et al., 2005a; Gardner et al., 2008; Lund, 2013). Rather, monitoring can divert managers from conservation priorities (Sheil, 2001) and exacerbate bureaucracy (Lindenmayer and Likens, 2010a). Although monitoring represents a major investment in "knowing in order to conserve", it often fails to integrate the information produced into decision-making (Danielsen et al., 2003) and appears to be "data rich but information poor" (Ward et al., 1986). Therefore, instead of increasing performance and cost-effectiveness of conservation strategies, monitoring can divert scarce resources (Nichols and Williams, 2006; Sheil, 2001).

Monitoring raises issues related to the interaction between knowledge production and decision-making in environmental policies. How can parks managers and their partners build a policy-relevant conservation science? During the last decade, in order to improve monitoring efficiency, scholars have proposed frameworks and typologies focusing predominantly on long-term ecological measures (e.g. Green et al., 2005; Lindenmayer and Likens, 2010b). However, the relationships between knowledge and action, scientific rigor and political value, as well as the social dimension of expertise have been poorly considered (but see literature on participatory and locally-based monitoring Danielsen et al., 2005b, 2010).

Monitoring combines both the need to preserve a scientific authority and the willingness to provide efficient management (Desrosières and Naish, 2002; Lascoumes and Le Galès, 2005; Rottenburg et al., 2015). Therefore, the implementation of monitoring programs relates to contexts where science and policy are difficult to distinguish. In order to frame this "policy-driven science", scholars have proposed different concepts such as regulatory (Jasanoff, 2009), postnormal (Funtowicz and Ravetz, 1993) or contextualized (Gibbons, 2000) sciences. They argue that the quality of expertise is highly related to the stakeholders' capacity to deal with complexity and uncertainty and stress the need to consider the production of scientific facts as

E-mail address: ruppert.vimal@idiv.de. 
socially and politically embedded (Carolan, 2006; Latour, 1987, 2004). Such approaches suggest a new model of rationality (Cronje and Fullan, 2003), in which the social drivers involved in the simultaneous construction of science and action appear as the key components of a successful innovation.

In this manuscript, I argue that monitoring and, by extension, evidencebased conservation, must rely on a new concept of the construction and use of knowledge for decision-making. Accordingly, I describe the relevant issues in terms of mediation and propose key objectives to be achieved by national parks managers and their partners. I then offer some practical recommendations as levers of action (Grundmann and Stehr, 2012) towards efficient monitoring programs in Africa.

\section{Monitoring in African tropical national parks}

My analysis and propositions rely on a combination between the existing literature and some recent observations made in the context of a larger project over seven national parks: Taï (Ivory Coast), Campo Ma'an (Cameroon), Odzala-Kokoua (Republic of Congo), Salonga and Virunga (Democratic Republic of Congo), Bwindi (Uganda) and Gunung Leuser (Indonesia). I surveyed all monitoring programs involving data collection i) on a permanent or regular basis, ii) still running, iii) inside or around the park in a $20 \mathrm{~km}$ buffer zone, iv) oriented towards management and/or research. I focused on scientific monitoring programs measuring the state of environmental issues for management purpose rather than on programs evaluating human resources management, accountability, administration or logistic (see Mascia et al., 2014 or Stem et al., 2005 for typologies of monitoring and evaluation). Appendix 1 lists all the monitoring programs identified in the considered parks between 2014 and 2016. Fig. 1 is based on these observations and provides a simple illustration of what I consider here as the main components of monitoring programs in such areas.

Although mainly focusing on ecosystems and wildlife, monitoring in African national parks also targets the production of data on illegal activities and local communities, involve a variety of organizations such as research institutes, non governmental organizations, private foundations or governmental authorities (Fig. 1). Parks and their partners do not only run programs within the parks' borders but as well in their surrounding areas. Such programs can be conducted on a permanent or a regular basis or for short time periods. In theory, when conducted for management purpose, monitoring in national parks aims at developing tourism, empowering communities and orienting law enforcement.

In a previous paper (Vimal et al., in press), we proposed a comprehensive analysis of the nature and role of these monitoring programs. Drawing on their limitations to guide management, this manuscript shows how they contribute to promote nature conservation (for instance by deciding what, where and how to protect) and to provide parks with a material dimension (monitoring automatically involves the provision of funds, equipments, human resources, etc.). We therefore conclude on the importance of the socio-political dimension of expertise and stress the need to "review the conditions under which a policyrelevant conservation science can be implemented".

\section{Dealing with social issues}

I argue that, by focusing on a linear model of knowledge transfer, conservationists underestimate the social forces and drivers underlying the production and use of monitoring for action and fail to provide policy-relevant knowledge (Game et al., 2015; Mathevet and Mauchamp, 2005). To have an impact on management, expertise for nature conservation should rather be implemented following a model of co-construction of knowledge production and decision making. This suggests that science and action are build simultaneously, influence each-others and thus become more relevant. It requires that environmental practitioners pay more attention to the complex socio-political processes involved in the construction and mobilization of policy-based evidences. In such "reflexive politicization" (Strassheim and Kettunen, 2014), stakeholders surpass the framework of data objectivity as a base for rational public action.

Concretely speaking, national parks should rely more heavily on social engineering in order to build a coherent expertise and make monitoring fully integrated to management strategies. "Measuring is not protecting" (Sheil, 2001). Proactive mediation is needed across services (monitoring, law enforcement, community), partners (NGOs, governmental authorities, research institutes) and hierarchical levels (field agents, officers, heads of service and managers). Parks must improve their capacity to plan knowledge production and actively use it to support, communicate and implement decision.

\subsection{Planning a strategy for knowledge production}

Overall, monitoring programs should be integrated through a
Who

Research institutes Non Governmental Organizations Foundations Governments

Aims

Community empowerment Law enforcement Tourism development

\section{Data collection methods}

Interview, Questionnaire, Focus group, Villager and agent report, Participatory mapping, Terrestrial transect, Clearing observation, Camera trap, Vegetation plots, Daily wildlife tracking, Aerial survey, Law enforcement patrol, Remote sensing
When

Regular

Permanent Temporary

Different steps

Planning

Data collection

Data analysis

Results interpretation

Decision

Communication Action

Where

Inside the park

Around the park In part of the park 
common strategy for the entire park. Parks managers must make efforts to set clear objectives and define priorities. To which management aim is a given program oriented? Why should it be more important than another one? Will data collected and their interpretation bring concrete gain to support management action?

\subsection{Using knowledge to support effective decisions}

Parks and their partners must move beyond data collection and analysis. To have an impact on management, monitoring programs must support and lead to clearly identified decisions. In some cases, such decision can even involve some deep changes in the parks' organization and governance (Vimal et al., in press).

\subsection{Communicating monitoring towards conservation actions}

Monitoring programs must be incorporated in the daily management of parks' territories. An effort should be made to communicate, spread the data, their interpretation and the related decisions to the different stakeholders involved. Monitoring would thus appear as a media towards active implementation of efficient conservation strategies.

\section{Three main objectives for monitoring in African tropical national parks}

\subsection{Less knowledge more action}

I argue that, in African tropical national parks, there is an overemphasis on quantitative knowledge and techniques. Ultimately, there can be a gap between the production of knowledge and the needs of parks with regards to management action. Parks should conduct monitoring following a more pragmatic approach (Danielsen et al., 2003). Priority must be given to programs with high potential impact on management. Hence, monitoring programs should i) have potential for daily and/or rapid action, ii) be objective-oriented, iii) focus more on causes than on consequences of biodiversity loss, iv) and define a targeted scale according to management needs. For instance, the monitoring of encroachments via aircraft photography in the Virunga national park allows direct intervention of the rangers. In contrast, the collection of data on both illegal activities and wildlife presence during rangers patrols or wildlife survey is more oriented towards long-term assessment and does not necessarily attempt to implement a specific action. The first priority of most national parks, or their intended purpose, is to protect the natural resources housed within their limits (Bruner et al., 2001). The most immediate challenge to parks' authorities and their partners is not one of science (Sheil, 2001) but of concrete actions towards biodiversity conservation. In the context of limited resources, both financial and otherwise, as is often the situation for tropical national parks, a better compromise is needed between concrete management and monitoring. Obviously, producing scientifically relevant knowledge might contribute to biodiversity loss reduction in the future, but this should not be performed at the expense of actions which could mitigate such decline now and on a daily basis (Sheil, 2002).

\subsection{Highlighting local communities}

In tropical national parks, there is a strong bias towards monitoring programs focusing on illegal activities and wildlife within the parks in comparison with those assessing local community activities around the parks. Over the seven parks we surveyed, only eight monitoring programs mainly divided in two parks (Virunga and Bwindi) target local communities while 42 focus on illegal activities and wildlife. It is increasingly recognized, however, that biodiversity conservation success is highly necessitated on direct/visible/realized benefit to local communities, as well as on their empowerment and willingness to protect said nature (Danielsen et al., 2000; Kaimowitz and Sheil, 2007). Therefore, the assessment of wildlife presence, distribution, ecology should not be considered as more important than, for instance, the evaluation of community livelihood. I argue that, in most of the considered parks, a better balance should be achieved between efforts to monitor wildlife and efforts to monitor communities. Parks' managers should invest more in monitoring community resources, behavior and perception in order to better orient management policies towards local development (see also Stem et al., 2005).

\subsection{Improving monitoring impact}

The task of using monitoring to implement evidence-based conservation involves different steps including data collection, analysis, results interpretation and communication (Fig. 1). Overall, as mentioned in the following statement, there is a need to increase the performance of parks regarding data analysis and results interpretation with respect to management: "Large quantities of data is collected (...) and is just stored. Little effort is made to analyze and disseminate the results for decision making" (Management plan 2014, Bwindi national park, p37). Monitoring is not a goal in itself; monitoring efficiency is a matter of how far data collected actually impact and drive management actions. Such guidance should not only be limited to one single policy but target complementary uses and impacts according to the different intended services of the parks. Indeed, data collected inside most parks are predominately oriented towards security (law enforcement service) whereas it could also help to direct community development policies. For instance, data focusing on illegal activities inside the parks could not only be used to orient future law enforcement patrols but also to target specific areas around the parks for sensitization and education of local communities.

\section{Concrete propositions}

\subsection{Training and empowering the staff}

Although most of the parks' agents are appropriately trained to collect data in the field, only few individuals are proficient in their use of computers and in data management and analysis. Similarly, my interviews revealed that only few people at the top of parks' organization are aware and able to justify the existence of monitoring programs and how they are theoretically integrated into the parks' strategy. Furthermore, parks' rangers rarely have access to the results and analysis of the monitoring programs to which they have contributed and generally have no opportunity to participate in or to comment on interpretation of results. Such a situation obviously limits the development of monitoring strategies and their relevance. Parks' managers must increase the capacity building of the staff and their interest towards monitoring programs.

\subsection{Centralizing and disseminating data and analysis}

Collected data, analysis and interpretation are often dispersed and rarely shared among programs (i.e. great ape habituation, clearing monitoring, wildlife surveys), services (research and monitoring, law enforcement, community) and partners (NGOs, governmental authorities, foundations, research institutes). They are typically fragmented and stored in the computers of the leaders of the programs, services or organizations. In Salonga, for instance, data collected through monitoring programs and their associated results seem to be rarely shared among the different organizations involved and the park's authority does not centralize them. Such a practice rules out the coherence of monitoring programs, their circulation and use at the park scale. Communication devices should be mobilized to promote complementary uses of monitoring programs and of their outputs. Parks' 
authorities should centralize the produced data and related reports within a single common database.

\subsection{Improving interactions between local management, global assessment and research}

Monitoring in tropical national parks does not only target local management but also the production of peer-reviewed research and the assessment of global environmental trends. Parks obviously represent privileged areas to conduct research and compute datasets for global trends' assessment. For instance, Bwindi national park is part of the TEAM network that aims to assess global changes in the tropics (www. teamnetwork.org). The Taï Chimpanzee Project is run since the 70's by a research institute to study the behavior, social structure and ecology of chimps. Similarly, one university monitors since decades presence, abundance and genetics of western gorillas among several clearings at Odzala-Kokoua national park. Although these programs have been useful to promote the conservation of primates in these regions as well as to equip parks with material and human resources, they can also divert them from their main mission. Thus there is a need to clearly identify the aim of a monitoring program at the very beginning of its implementation. Furthermore, whenever possible, an increasing complementarity must be found between these three different goals. How could a global assessment monitoring program or a research-based monitoring program benefit park management? Parks' resources should be proportionally involved according to the potential of such program for local management needs.

\subsection{Reforming the funding/reporting system}

Management in tropical national parks is easily "sidetracked by initiatives that promise some support" (Sheil, 2001). Donors in such areas have the power to guide parks' activities based on their own goals. They usually support programs politically correct and scientifically sustained which can be easily measurable such as wildlife monitoring. Furthermore funding increasingly involves reporting that can divert stakeholders from practical management and exacerbate bureaucracy (Vimal et al., in press). When not directly targeting management actions, funding should promote monitoring which also focuses on communities around the parks and gives priority to more pragmatic knowledge. Project assessment should clearly separate "performance measurement" (which aims at reporting program's progress) from "impact evaluation" (which assesses the changes induced by a funded program) (Mascia et al., 2014). In the case of monitoring, impact evaluation should clearly mention how collected data was interpreted and which management actions have been identified accordingly.

\subsection{Giving voice to human sciences}

The organizations historically involved in tropical national parks promoted over time a rationalist approach of the parks management (Adams and Hutton, 2007). Their concept of nature protection is characterized by a strong emphasize on quantitative scientific knowledge and generally mainly focuses on ecological issues (see organizations in charge of monitoring programs and their partners in Appendix
1). I argue that parks would benefit from an increasing diversity of expertise. I particularly stress the need to improve the representativeness of human sciences (Bennett et al., 2016). The presence of economists, sociologists, political scientists, geographers, psychologists or communication experts would allow to build a better compromise between technical data, socio-political issues and decision making.

\subsection{Strengthening governance capacity}

Parks in Africa can follow various management configurations such as state-centralized management (e.g. Taï, Bwindi), co or multi-partners management (e.g. Campo Ma'an, Salonga) or private management (e.g. Virunga, Odzala-Kokoua). Whatever the configuration, different partners follow different goals and tropical national parks often suffer from a lack of coherence, the absence of leadership and of a common strategy among the different stakeholders involved (Bruyere, 2015; Lindenmayer and Likens, 2010b). Although increasing governance is a complex and long-term issue, a first step towards more integrative knowledge production could be the effective establishment of scientific/management council. Such participatory committee already exists in some of the considered parks (e.g. Salonga, Taii). Nonetheless, they are often used to report and validate existing results rather than to decide and orient future programs. Skills of animation are needed such that various stakeholders could discuss parks' strategies, define priorities, share results and interpretations and direct decisions collectively.

\section{Conclusion}

The framework proposed in this manuscript is directed towards a more policy-relevant approach of conservation science (Game et al., 2015). I argue that parks' managers/directorships should focus more on the social context in which knowledge production can lead to decisionmaking. This involves a more reflective approach of data collection, interpretation, and communication, and calls for a new perception of the relationship between knowledge and action towards the implementation of evidence-based policies.

This manuscript highlights the central position of monitoring as a tool for conservation in tropical national parks. Reforming monitoring does not only assume a new perception of science but simultaneously relies on deep changes in parks' administration, organization and governance. Monitoring programs can therefore be considered as intermediary objects (Vimal and Mathevet, 2011; Vinck, 1999). By improving the social dimension of their implementation, stakeholders involved in parks' management can make "common cause" (Stengers, 2002) towards efficient conservation strategies.

\section{Acknowledgment}

This project was funded by the Robert Bosch Foundation and hosted by the German Centre for Integrative Biodiversity (iDiv) and the Max Planck Institute for Evolutionary Anthropology. I am particularly grateful to all the staff of national parks and their partners for their contribution and willingness to participate to the project. Thanks to Erin Wessling for her advise on a previous version of the manuscript.

\section{Appendix 1}

Law enforcement monitoring

\begin{tabular}{|c|c|c|c|c|c|c|c|c|c|}
\hline Park & Mission & Aim & Area & Frequency & Collection method & $\begin{array}{l}\text { Features of } \\
\text { interest }\end{array}$ & Analysis & Who & $\begin{array}{l}\text { Technical } \\
\text { partners }\end{array}$ \\
\hline $\begin{array}{l}\text { Campo } \\
\text { Ma'an }\end{array}$ & $\begin{array}{l}\text { Law } \\
\text { enforcement }\end{array}$ & Management & $\begin{array}{l}\text { The } \\
\text { whole }\end{array}$ & Permanent & Patrol & $\begin{array}{l}\text { Illegal } \\
\text { activities and }\end{array}$ & $\begin{array}{l}\text { Identification } \\
\text { and distribution }\end{array}$ & MINFOF & $\begin{array}{l}\text { AWF and } \\
\text { WWF }\end{array}$ \\
\hline
\end{tabular}




\begin{tabular}{|c|c|c|c|c|c|c|c|c|c|c|c|}
\hline & patrol & & park & \multicolumn{2}{|c|}{ Permanent } & \multicolumn{2}{|l|}{ Patrol } & large mammals & & & \\
\hline $\begin{array}{l}\text { Odzala- } \\
\text { Koko- } \\
\text { ua }\end{array}$ & $\begin{array}{l}\text { Elephant } \\
\text { tracking }\end{array}$ & Management & $\begin{array}{l}\text { The } \\
\text { whole } \\
\text { park }\end{array}$ & \multicolumn{2}{|c|}{ Permanent } & \multicolumn{2}{|l|}{ Patrol } & 7 elephants & $\begin{array}{l}\text { Daily track and } \\
\text { position, home } \\
\text { range, ecology }\end{array}$ & AP & \\
\hline $\begin{array}{l}\text { Odzala- } \\
\text { Koko- } \\
\text { ua }\end{array}$ & Elephant killing & Management & $\begin{array}{l}\text { The } \\
\text { whole } \\
\text { park }\end{array}$ & \multicolumn{2}{|c|}{ Permanent } & \multicolumn{2}{|l|}{ Patrol } & $\begin{array}{l}\text { Ivory stock and } \\
\text { carcasses }\end{array}$ & Quantity & AP & $\begin{array}{l}\text { MIKE- } \\
\text { CITES }\end{array}$ \\
\hline Salonga & $\begin{array}{l}\text { Law } \\
\text { enforcement } \\
\text { patrol }\end{array}$ & Management & $\begin{array}{l}\text { The } \\
\text { whole } \\
\text { park }\end{array}$ & \multicolumn{2}{|c|}{ Permanent } & \multicolumn{2}{|l|}{ Patrol } & $\begin{array}{l}\text { Illegal } \\
\text { activities and } \\
\text { large mammals }\end{array}$ & $\begin{array}{l}\text { Identification } \\
\text { and distribution }\end{array}$ & ICCN & $\begin{array}{l}\text { WCS, } \\
\text { WWF, } \\
\text { ZSM, MPI }\end{array}$ \\
\hline Virunga & $\begin{array}{l}\text { Elephant } \\
\text { tracking }\end{array}$ & Management & $\begin{array}{l}\text { The } \\
\text { whole } \\
\text { park }\end{array}$ & \multicolumn{2}{|c|}{ Permanent } & \multicolumn{2}{|c|}{$\begin{array}{l}\text { GPS necklace } \\
\text { tracking }\end{array}$} & 15 elephants & $\begin{array}{l}\text { Daily track and } \\
\text { position, home } \\
\text { range, ecology }\end{array}$ & \multicolumn{2}{|l|}{$\begin{array}{l}\text { Virunga } \\
\text { foundation }\end{array}$} \\
\hline Virunga & $\begin{array}{l}\text { Invasion of the } \\
\text { park } \\
\text { (agriculture and } \\
\text { rebels) }\end{array}$ & Management & $\begin{array}{l}\text { The } \\
\text { whole } \\
\text { park }\end{array}$ & \multicolumn{2}{|c|}{ Permanent } & \multicolumn{2}{|c|}{$\begin{array}{l}\text { Aircraft survey } \\
\text { photography }\end{array}$} & $\begin{array}{l}\text { Illegal logging, } \\
\text { encroachment } \\
\text { and rebels }\end{array}$ & $\begin{array}{l}\text { Identification } \\
\text { and distribution }\end{array}$ & $\begin{array}{l}\text { Virunga } \\
\text { foundation }\end{array}$ & \\
\hline Bwindi & $\begin{array}{l}\text { Law } \\
\text { enforcement } \\
\text { patrol }\end{array}$ & Management & $\begin{array}{l}\text { The } \\
\text { whole } \\
\text { park }\end{array}$ & \multicolumn{2}{|c|}{ Permanent } & \multicolumn{2}{|l|}{ Patrol } & $\begin{array}{l}\text { Illegal } \\
\text { activities and } \\
\text { large mammals }\end{array}$ & $\begin{array}{l}\text { Identification } \\
\text { and distribution }\end{array}$ & UWA & \\
\hline \multicolumn{12}{|c|}{ Ecological monitoring } \\
\hline Park & Mission & Aim & Area & & Freq & uency & $\begin{array}{l}\text { Collection } \\
\text { method }\end{array}$ & $\begin{array}{l}\text { Features of } \\
\text { interest }\end{array}$ & Analysis & Who & $\begin{array}{l}\text { Technical } \\
\text { partners }\end{array}$ \\
\hline Bwindi & $\begin{array}{l}\text { Mountain } \\
\text { gorilla census }\end{array}$ & $\begin{array}{l}\text { Management/ } \\
\text { research }\end{array}$ & $\begin{array}{l}\text { The wh } \\
\text { park }\end{array}$ & & $\begin{array}{l}\text { Ever } \\
\text { years }\end{array}$ & & Transect & $\begin{array}{l}\text { Gorillas, large } \\
\text { mammals }\end{array}$ & $\begin{array}{l}\text { Parasitology, } \\
\text { genetic } \\
\text { identification, } \\
\text { density, } \\
\text { distribution } \\
\text { and family } \\
\text { structure of } \\
\text { gorillas; large } \\
\text { mammals and } \\
\text { illegal activities } \\
\text { relative density } \\
\text { and } \\
\text { distribution }\end{array}$ & IGCP & $\begin{array}{l}\text { DFGFI, } \\
\text { Gorilla } \\
\text { doctors, } \\
\text { MPI, } \\
\text { MGVP, } \\
\text { ITFC }\end{array}$ \\
\hline Bwindi & $\begin{array}{l}\text { Habituated } \\
\text { mountain } \\
\text { gorillas } \\
\text { monitoring }\end{array}$ & Management & 14 Grol & & Perm & lanent & Tracking & Gorillas & $\begin{array}{l}\text { Vital domain, } \\
\text { number and } \\
\text { health } \\
\text { checking }\end{array}$ & UWA & $\begin{array}{l}\text { MGVP, } \\
\text { Gorilla } \\
\text { doctors }\end{array}$ \\
\hline Bwindi & $\begin{array}{l}\text { Global change } \\
\text { monitoring }\end{array}$ & $\begin{array}{l}\text { Management/ } \\
\text { research }\end{array}$ & $\begin{array}{l}\text { The wh } \\
\text { park }\end{array}$ & & Perm & ianent & $\begin{array}{l}\text { Camera trap, } \\
\text { vegetation } \\
\text { plots, } \\
\text { climate }\end{array}$ & $\begin{array}{l}\text { Vegetation, } \\
\text { wildlife, } \\
\text { climate }\end{array}$ & $\begin{array}{l}\text { Distribution, } \\
\text { growth rate, } \\
\text { temporal } \\
\text { evolution }\end{array}$ & ITFC & TEAM \\
\hline
\end{tabular}




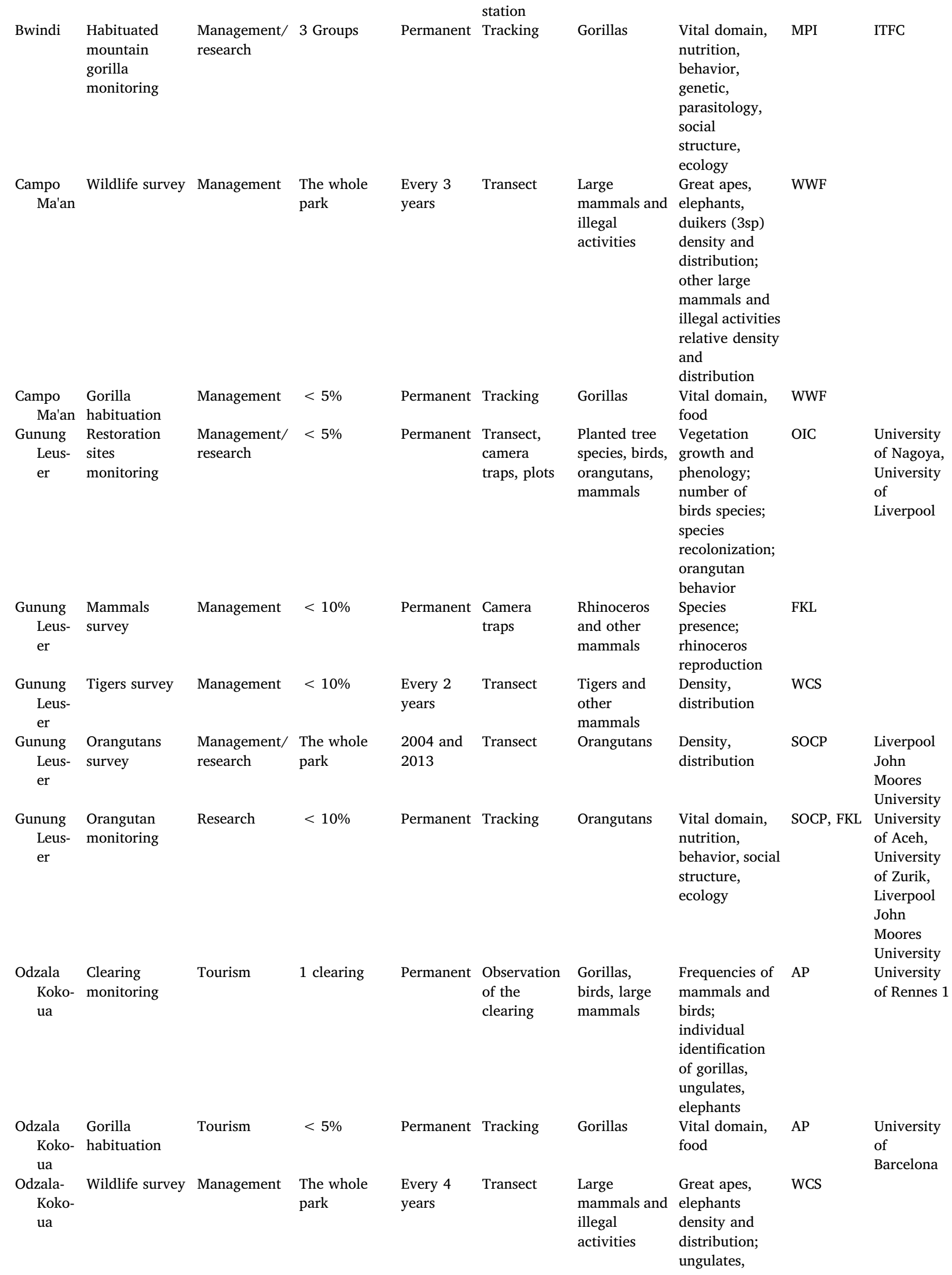




\begin{tabular}{|c|c|c|c|c|c|c|c|c|c|}
\hline & & & & & & & $\begin{array}{l}\text { illegal activities } \\
\text { relative density } \\
\text { and } \\
\text { distribution }\end{array}$ & & \\
\hline Salonga & Wildlife survey & Management & $\begin{array}{l}\text { The whole } \\
\text { park }\end{array}$ & $\begin{array}{l}2004 \text { and } \\
2015\end{array}$ & Transect & $\begin{array}{l}\text { Large } \\
\text { mammals and } \\
\text { illegal } \\
\text { activities }\end{array}$ & $\begin{array}{l}\text { Great apes, } \\
\text { elephants } \\
\text { density and } \\
\text { distribution; } \\
\text { ungulates, } \\
\text { illegal activities } \\
\text { relative density } \\
\text { and } \\
\text { distribution }\end{array}$ & $\begin{array}{l}\text { WCS, MPI, } \\
\text { ZSM }\end{array}$ & \\
\hline Salonga & $\begin{array}{l}\text { Elephant } \\
\text { monitoring } \\
\text { around a } \\
\text { clearing }\end{array}$ & Management & 1 Clearing & Permanent & $\begin{array}{l}\text { Camera } \\
\text { traps }\end{array}$ & Elephants & Presence & WCS & \\
\hline Salonga & $\begin{array}{l}\text { Carbon } \\
\text { monitoring }\end{array}$ & Research & 3 Parcels & Permanent & $\begin{array}{l}\text { Vegetation } \\
\text { plots }\end{array}$ & 3 Forest types & $\begin{array}{l}\text { Biomass and } \\
\text { botanical } \\
\text { composition }\end{array}$ & WCS & $\begin{array}{l}\text { CTFS, } \\
\text { University } \\
\text { of Leeds }\end{array}$ \\
\hline Salonga & $\begin{array}{l}\text { Bonobo } \\
\text { monitoring }\end{array}$ & Research & 1 Site $;<5 \%$ & Permanent & $\begin{array}{l}\text { Tracking, } \\
\text { camera trap, } \\
\text { transect }\end{array}$ & Bonobos & $\begin{array}{l}\text { Vital domain, } \\
\text { nutrition, } \\
\text { behavior, } \\
\text { genetic, } \\
\text { parasitology, } \\
\text { social } \\
\text { structure, } \\
\text { ecology }\end{array}$ & MPI & \\
\hline Taї & Wildlife survey & Management & $\begin{array}{l}\text { The whole } \\
\text { park }\end{array}$ & Every year & Transect & $\begin{array}{l}\text { Large } \\
\text { mammals, } \\
\text { birds and } \\
\text { illegal } \\
\text { activities }\end{array}$ & $\begin{array}{l}\text { Great apes, } \\
\text { elephants, } \\
\text { bovidae, tale } \\
\text { apes density } \\
\text { and } \\
\text { distribution; } \\
\text { birds, other } \\
\text { large } \\
\text { mammals, } \\
\text { illegal activities } \\
\text { relative density }\end{array}$ & OIPR & WCF \\
\hline
\end{tabular}




\begin{tabular}{|c|c|c|c|c|c|c|c|c|c|c|c|c|c|c|}
\hline \\
\hline & & & & & & & & & & & & $\begin{array}{l}\text { and } \\
\text { distribution }\end{array}$ & & \\
\hline Taї & \multicolumn{2}{|c|}{$\begin{array}{l}\text { Chimpanzee } \\
\text { habituation }\end{array}$} & \multicolumn{2}{|l|}{ Tourism } & \multicolumn{2}{|c|}{$<5 \%$} & Permanent & \multicolumn{2}{|c|}{$\begin{array}{l}\text { Chimpanzee } \\
\text { tracking }\end{array}$} & \multicolumn{2}{|c|}{ Chimpanzee } & $\begin{array}{l}\text { Vital domain, } \\
\text { food }\end{array}$ & OIPR & WCF, MPI \\
\hline Taї & \multicolumn{2}{|c|}{$\begin{array}{l}\text { Mangabey and } \\
\text { Red Colobus } \\
\text { habituation }\end{array}$} & \multicolumn{2}{|l|}{ Tourism } & \multicolumn{2}{|c|}{$<5 \%$} & Permanent & \multicolumn{2}{|c|}{ Tracking } & \multicolumn{2}{|c|}{$\begin{array}{l}\text { Mangabey, } \\
\text { Red Colobus }\end{array}$} & $\begin{array}{l}\text { Vital domain, } \\
\text { food, behavior }\end{array}$ & WCF & MPI \\
\hline Taï & \multicolumn{2}{|c|}{$\begin{array}{l}\text { Ecological and } \\
\text { law } \\
\text { enforcement } \\
\text { monitoring }\end{array}$} & \multicolumn{2}{|l|}{ Research } & \multicolumn{2}{|c|}{$<5 \%$} & Permanent & \multicolumn{2}{|c|}{ Transect } & \multicolumn{2}{|c|}{$\begin{array}{l}\text { Large } \\
\text { mammals, } \\
\text { vegetation } \\
\text { change, } \\
\text { illegal } \\
\text { activities }\end{array}$} & $\begin{array}{l}\text { Distribution } \\
\text { and temporal } \\
\text { evolution of } \\
\text { wildlife; Impact } \\
\text { of law } \\
\text { enforcement }\end{array}$ & WCF & MPI \\
\hline Taï & \multicolumn{2}{|l|}{$\begin{array}{l}\text { Taï } \\
\text { chimpanzee } \\
\text { and monkey } \\
\text { projects }\end{array}$} & \multicolumn{2}{|l|}{ Research } & \multicolumn{2}{|c|}{5 Sites; < 5\% } & Permanent & \multicolumn{2}{|c|}{$\begin{array}{l}\text { Tracking, } \\
\text { camera trap, } \\
\text { transect }\end{array}$} & \multicolumn{2}{|c|}{$\begin{array}{l}\text { Chimpanzees } \\
\text { and other } \\
\text { primates }\end{array}$} & $\begin{array}{ll}\text { Vital domain, } & \mathrm{M} \\
\text { nutrition, } & \mathrm{U} \\
\text { behavior, } & \mathrm{O} \\
\text { genetic, } & \mathrm{N} \\
\text { parasitology, } & \\
\text { social } & \\
\text { structure, } & \\
\text { ecology } & \end{array}$ & $\begin{array}{l}\text { MPI, } \\
\text { University } \\
\text { of } \\
\text { Neuchatel }\end{array}$ & CSRS \\
\hline Virunga & \multicolumn{2}{|c|}{$\begin{array}{l}\text { Mountain } \\
\text { gorilla census }\end{array}$} & \multicolumn{2}{|c|}{$\begin{array}{l}\text { Management/ } \\
\text { research }\end{array}$} & \multicolumn{2}{|c|}{$<10 \%$} & $\begin{array}{l}\text { Every } 5 \\
\text { years }\end{array}$ & \multicolumn{2}{|c|}{ Transect } & \multicolumn{2}{|c|}{$\begin{array}{l}\text { Gorillas, large } \\
\text { mammals }\end{array}$} & $\begin{array}{l}\text { Parasitology, } \\
\text { genetic } \\
\text { identification, } \\
\text { density, } \\
\text { distribution } \\
\text { and family } \\
\text { structure of } \\
\text { gorillas; large } \\
\text { mammals and } \\
\text { illegal activities } \\
\text { relative density } \\
\text { and } \\
\text { distribution }\end{array}$ & IGCP & $\begin{array}{l}\text { DFGFI, } \\
\text { Gorilla } \\
\text { doctors, } \\
\text { MPI, } \\
\text { MGVP, } \\
\text { ITFC }\end{array}$ \\
\hline Virunga & $\begin{array}{l}\text { Hippopotam } \\
\text { survey }\end{array}$ & & Manageme & & $<4$ & $\begin{array}{l}20 \\
20\end{array}$ & $\begin{array}{l}2011 \\
2015\end{array}$ & $\begin{array}{l}\text { Transe } \\
\text { (aerial } \\
\text { pedest }\end{array}$ & $\begin{array}{l}\text { and } \\
\text { rian) }\end{array}$ & Hipop & otamus & $\begin{array}{l}\text { Density, } \\
\text { distribution, } \\
\text { relation with } \\
\text { law } \\
\text { enforcement } \\
\text { effort }\end{array}$ & WCS & \\
\hline Virunga & $\begin{array}{l}\text { Savannas } \\
\text { wildlife surv }\end{array}$ & & Manageme & & $<7$ & $\begin{array}{l}\text { Ev } \\
\text { ye }\end{array}$ & $\begin{array}{l}\text { Every } 5 \\
\text { jears }\end{array}$ & $\begin{array}{l}\text { Aircraf } \\
\text { transec }\end{array}$ & & $\begin{array}{l}\text { Large } \\
\text { mamn } \\
\text { sp) }\end{array}$ & als $(7$ & $\begin{array}{l}\text { Density, } \\
\text { distribution }\end{array}$ & WCS & \\
\hline Virunga & $\begin{array}{l}\text { Habituated } \\
\text { mountain } \\
\text { gorillas } \\
\text { monitoring }\end{array}$ & & $\begin{array}{l}\text { Manageme } \\
\text { tourism }\end{array}$ & ent/ & $8 \mathrm{Grc}$ & bups & Permanent & Trackiı & & Gorill & & $\begin{array}{l}\text { Vital domain, } \\
\text { number and } \\
\text { health } \\
\text { checking }\end{array}$ & ICCN & $\begin{array}{l}\text { MGVP, } \\
\text { Gorilla } \\
\text { doctors }\end{array}$ \\
\hline & & & & & & & Community & $y$ moni & itoring & & & & & \\
\hline Park & Mission & Air & & Area & & Frequency & $\begin{array}{l}\text { Collectior } \\
\text { method }\end{array}$ & & $\begin{array}{l}\text { Featur } \\
\text { interes }\end{array}$ & $\begin{array}{l}\text { es of } \\
\text { t }\end{array}$ & Analysis & & Who & $\begin{array}{l}\text { Technical } \\
\text { partners }\end{array}$ \\
\hline $\begin{array}{l}\text { Campo } \\
\text { Ma'- } \\
\text { an }\end{array}$ & $\begin{array}{l}\text { Human/ } \\
\text { wildlife } \\
\text { conflict }\end{array}$ & $\mathrm{Ma}$ & anagement & $\begin{array}{l}\text { All } \\
\text { arou } \\
\text { the }\end{array}$ & park & Permanent & $\begin{array}{l}\text { Villagers } \\
\text { report }\end{array}$ & & $\begin{array}{l}\text { Damag } \\
\text { wildlif } \\
\text { human } \\
\text { activit }\end{array}$ & $\begin{array}{l}\text { ges of } \\
\text { e on } \\
\text { ies }\end{array}$ & $\begin{array}{l}\text { Number } \\
\text { wildlife } \\
\text { of dama }\end{array}$ & $\begin{array}{l}\text { r, distribution, } \\
\text { involved, and type } \\
\text { age }\end{array}$ & WWF & $\begin{array}{l}\text { CIRAD, } \\
\text { OFAC, FAO }\end{array}$ \\
\hline Virunga & $\begin{array}{l}\text { Edouard } \\
\text { Lake fishing } \\
\text { activity }\end{array}$ & & anagement & $\begin{array}{l}\text { Edo } \\
\text { Lake }\end{array}$ & $\begin{array}{l}\text { uard } \\
\text { e }\end{array}$ & Permanent & $\begin{array}{l}\text { Interview } \\
\text { field } \\
\text { prospecti }\end{array}$ & $\begin{array}{l}\text { vs and } \\
\text { ion }\end{array}$ & Fishes & stock & $\begin{array}{l}\text { Fisherie } \\
\text { delimita } \\
\text { areas }\end{array}$ & $\begin{array}{l}\text { statistics, } \\
\text { ation of spawning }\end{array}$ & WCS & WWF \\
\hline Virunga & $\begin{array}{l}\text { Monitoring } \\
\text { community } \\
\text { forests }\end{array}$ & & anagement & $<1$ & $10 \%$ & Permanent & $\begin{array}{l}\text { Field } \\
\text { prospecti } \\
\text { focus gro }\end{array}$ & ion, & Land $\mathrm{u}$ & & $\begin{array}{l}\text { Delimit } \\
\text { croppin } \\
\text { resource }\end{array}$ & $\begin{array}{l}\text { ation of area for } \\
g \text {, conservation and } \\
\text { e use }\end{array}$ & WWF I & $\begin{array}{l}\text { Local } \\
\text { communities }\end{array}$ \\
\hline Virunga & $\begin{array}{l}\text { Delimitation } \\
\text { of } \\
\text { community }\end{array}$ & & anagement & & $10 \%$ & Permanent & $\begin{array}{ll}\text { t } & \text { Field } \\
\text { prospecti }\end{array}$ & & $\begin{array}{l}\text { Croppi } \\
\text { area }\end{array}$ & & $\begin{array}{l}\text { Delimite } \\
\text { area; } \mathrm{M} \\
\text { with pa }\end{array}$ & $\begin{array}{l}\text { ation of cropping } \\
\text { onitoring conflict } \\
\text { rk boundaries }\end{array}$ & WWF & \\
\hline
\end{tabular}




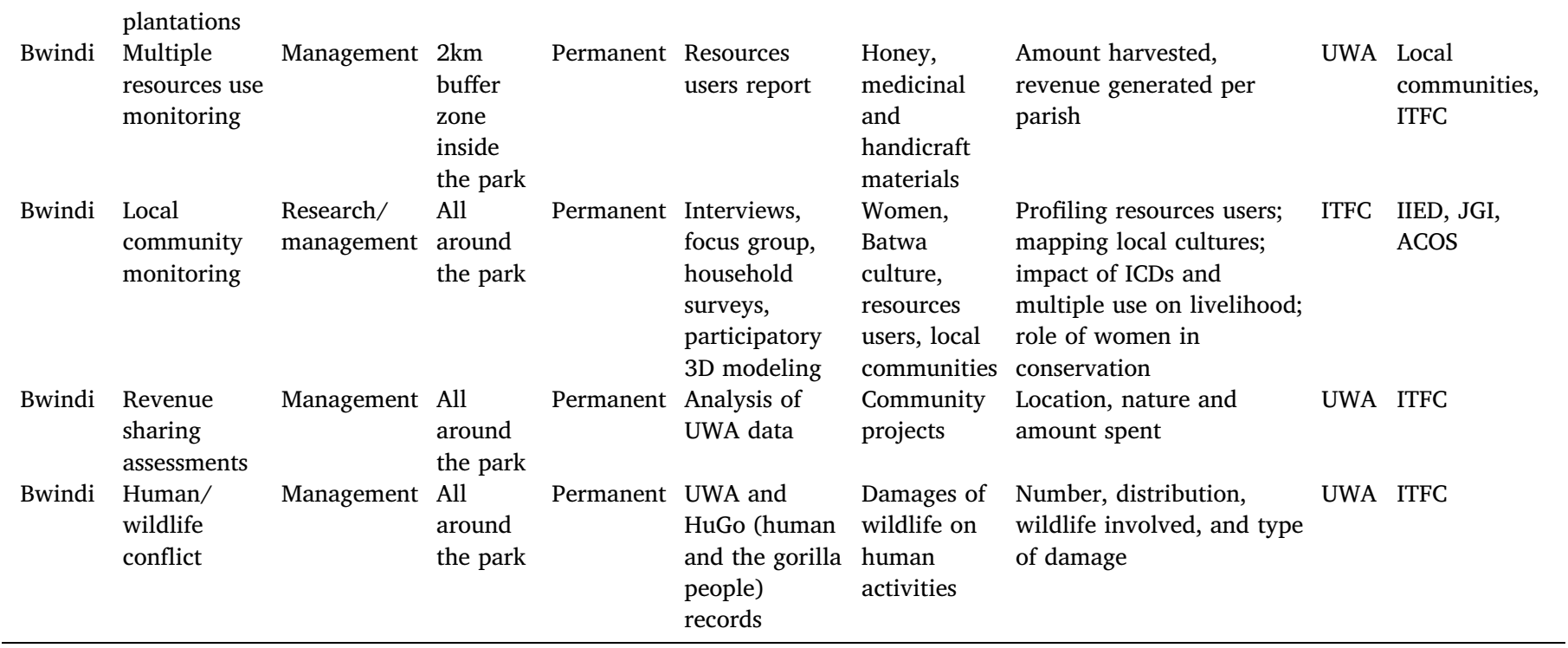

\section{References}

Adams, W.M., Hutton, J., 2007. People, parks and poverty: Political ecology and biodiversity conservation. Conserv. Soc. 5, 147.

Beaudrot, L., Ahumada, J.A., O'Brien, T., Alvarez-Loayza, P., Boekee, K., Campos-Arceiz, A., Eichberg, D., Espinosa, S., Fegraus, E., Fletcher, C., Gajapersad, K., Hallam, C., Hurtado, J., Jansen, P.A., Kumar, A., Larney, E., Lima, M.G.M., Mahony, C., Martin, E.H., McWilliam, A., Mugerwa, B., Ndoundou-Hockemba, M., Razafimahaimodison, J.C., Romero-Saltos, H., Rovero, F., Salvador, J., Santos, F., Sheil, D., Spironello, W.R., Willig, M.R., Winarni, N.L., Zvoleff, A., Andelman, S.J., 2016. Standardized assessment of biodiversity trends in tropical forest protected areas: The end is not in sight. PLoS Biol. 14, e1002357. http://dx.doi.org/10.1371/journal.pbio.1002357.

Bennett, N.J., Roth, R., Klain, S.C., Chan, K.M.A., Clark, D.A., Cullman, G., Epstein, G., Nelson, M.P., Stedman, R., Teel, T.L., et al., 2016. Mainstreaming the social sciences in conservation. Conserv. Biol (n/a-n/a).

Bruner, A.G., Gullison, R.E., Rice, R.E., Fonseca, G.A.B. da, 2001. Effectiveness of parks in protecting tropical biodiversity. Science 291, 125-128.

Bruyere, B.L., 2015. Giving direction and clarity to conservation leadership. Conserv. Lett. 8, 378-382.

Burton, A.C., 2012. Critical evaluation of a long-term, locally-based wildlife monitoring program in West Africa. Biodivers. Conserv. 21, 3079-3094.

Carolan, M.S., 2006. Science, expertise, and the democratization of the decision-making process. Soc. Nat. Resour. 19, 661-668.

Cronje, R., Fullan, A., 2003. Evidence-based medicine: toward a new definition of 'rational' medicine. Health (N. Y.) 7, 353-369.

Danielsen, F., Balete, D.S., Poulsen, M.K., Enghoff, M., Nozawa, C.M., Jensen, A.E., 2000. A simple system for monitoring biodiversity in protected areas of a developing country. Biodivers. Conserv. 9, 1671-1705.

Danielsen, F., Mendoza, M.M., Alviola, P., Balete, D.S., Enghoff, M., Poulsen, M.K., Jensen, A.E., 2003. Biodiversity monitoring in developing countries: what are we trying to achieve? Oryx 37, 407-409.

Danielsen, F., Jensen, A.E., Alviola, P.A., Balete, D.S., Mendoza, M., Tagtag, A., Custodio, C., Enghoff, M., 2005a. Does monitoring matter? A quantitative assessment of management decisions from locally-based monitoring of protected areas. Biodivers. Conserv. 14, 2633-2652.

Danielsen, F., Burgess, N.D., Balmford, A., 2005b. Monitoring matters: examining the potential of locally-based approaches. Biodivers. Conserv. 14, 2507-2542.

Danielsen, F., Burgess, N.D., Jensen, P.M., Pirhofer-Walzl, K., 2010. Environmental monitoring: the scale and speed of implementation varies according to the degree of peoples involvement. J. Appl. Ecol. 47, 1166-1168.

Desrosières, A., Naish, C., 2002. The Politics of Large Numbers: A History of Statistical Reasoning. Harvard University Press.

Funtowicz, S.O., Ravetz, J.R., 1993. Science for the post-normal age. Futures 25, 739-755.

Game, E.T., Schwartz, M.W., Knight, A.T., 2015. Policy relevant conservation science. Conserv. Lett. 8, 309-311.

Gardner, T.A., Barlow, J., Araujo, I.S., Ávila-Pires, T.C., Bonaldo, A.B., Costa, J.E., Esposito, M.C., Ferreira, L.V., Hawes, J., Hernandez, M.I.M., et al., 2008. The costeffectiveness of biodiversity surveys in tropical forests. Ecol. Lett. 11, 139-150.

Gibbons, M., 2000. Mode 2 society and the emergence of context-sensitive science. Sci. Public Policy 27, 159-163.

Green, R.E., Balmford, A., Crane, P.R., Mace, G.M., Reynolds, J.D., Turner, R.K., 2005. A framework for improved monitoring of biodiversity: responses to the world summit on sustainable development. Conserv. Biol. 19, 56-65.

Grundmann, R., Stehr, N., 2012. The Power of Scientific Knowledge: From Research to Public Policy. Cambridge University Press.

Jasanoff, S., 2009. The Fifth Branch: Science Advisers as Policymakers. Harvard
University Press.

Kaimowitz, D., Sheil, D., 2007. Conserving what and for whom? Why conservation should help meet basic human needs in the tropics. Biotropica 39, 567-574.

Lascoumes, P., Le Galès, P., 2005. Gouverner par les instruments. Presses de Sciences Po, Paris, France.

Latour, B., 1987. Science in Action: How to Follow Scientists and Engineers Through Society. Harvard University Press.

Latour, B., 2004. Politics of Nature: How to Bring the Sciences Into Democracy. Harvard University Press.

Lindenmayer, D.B., Likens, G.E., 2010a. Effective Ecological Monitoring.

Lindenmayer, D.B., Likens, G.E., 2010b. The science and application of ecological monitoring. Biol. Conserv. 143, 1317-1328.

Lund, J.F., 2013. Towards a more balanced view on the potentials of locally-based monitoring. Biodivers. Conserv. 23, 237-239.

Margoluis, R., Salafsky, N., 1998. Measures of Success: Designing, Managing, and Monitoring Conservation and Development Projects. Island Press, Washington, W, USA.

Mascia, M.B., Pailler, S., Thieme, M.L., Rowe, A., Bottrill, M.C., Danielsen, F., Geldmann, J., Naidoo, R., Pullin, A.S., Burgess, N.D., 2014. Commonalities and complementarities among approaches to conservation monitoring and evaluation. Biol. Conserv. $169,258-267$.

Mathevet, R., Mauchamp, A., 2005. Evidence-based conservation: dealing with social issues. Trends Ecol. Evol. 20, 422-423.

Miteva, D.A., Pattanayak, S.K., Ferraro, P.J., 2012. Evaluation of biodiversity policy instruments: what works and what doesn't? Oxf. Rev. Econ. Policy 28, 69-92.

Nichols, J.D., Williams, B.K., 2006. Monitoring for conservation. Trends Ecol. Evol. 21, 668-673.

Pullin, A.S., Knight, T.M., 2001. Effectiveness in conservation practice: pointers from medicine and public health. Conserv. Biol. 15, 50-54.

Rottenburg, R., Merry, S.E., Park, S.-J., Mugler, J., 2015. The World of Indicators: The Making of Governmental Knowledge Through Quantification. Cambridge University Press.

Saout, S.L., Hoffmann, M., Shi, Y., Hughes, A., Bernard, C., Brooks, T.M., Bertzky, B., Butchart, S.H.M., Stuart, S.N., Badman, T., et al., 2013. Protected areas and effective biodiversity conservation. Science $342,803-805$.

Sheil, D., 2001. Conservation and biodiversity monitoring in the tropics: realities, priorities, and distractions. Conserv. Biol. 15, 1179-1182.

Sheil, D., 2002. Why doesn't biodiversity monitoring support conservation priorities in the tropics? Unasylva 53.

Stem, C., Margoluis, R., Salafsky, N., Brown, M., 2005. Monitoring and evaluation in conservation: a review of trends and approaches. Conserv. Biol. 19, 295-309.

Stengers, I., 2002. Sciences et pouvoirs. La démocratie face à la technoscience. La Découverte, Paris, France.

Strassheim, H., Kettunen, P., 2014. When does evidence-based policy turn into policybased evidence? Configurations, contexts and mechanisms. Evid. Policy J. Res. Debate Pract. 10, 259-277.

Tranquilli, S., Abedi-Lartey, M., Abernethy, K., Amsini, F., Asamoah, A., Balangtaa, C., Blake, S., Bouanga, E., Breuer, T., Brncic, T.M., et al., 2014. Protected areas in tropical Africa: assessing threats and conservation activities. PLoS One 9, e114154.

Vimal, R., Mathevet, R., 2011. La carte et le territoire: le réseau écologique à l'épreuve de l'assemblée cartographique. Cybergeo Eur. J, Geogr.

Vimal, R., Gatsio, T., Mathevet, R., 2017;al., in press. Monitoring in tropical national parks: the power of indicators. Conserv. Soc (in press).

Vinck, D., 1999. Les objets intermédiaires dans les réseaux de coopération scientifique. Contribution à la prise en compte des objets dans les dynamiques sociales. Rev. Fr. Sociol. XL, 385-414.

Ward, R.C., Loftis, J.C., McBride, G.B., 1986. The "data-rich but information-poor" syndrome in water quality monitoring. Environ. Manag. 10, 291-297. 